\title{
A Study on the Improvement of English Writing Competence for College Students
}

\author{
Xiu Zeng \\ Foreign Language School, Nanchang Normal University, Nanchang, Jiangxi, China
}

\begin{abstract}
English writing has long been viewed as a challenge to most Chinese college students because of their weak language foundation, limited expanse of ideas and inadequate targeted practice for the production of satisfactory written work. Attention has constantly been directed to the low efficiency in the writing teaching. By adopting some widely used approaches, this paper tries to explore efficient ways to integrate writing into the whole process of English learning and teaching. The focus of this paper is put on the suggested solutions to writing problems and the improvement in the efficiency of English writing learning and teaching.
\end{abstract}

Index Terms - approaches, improvement, college students

\section{INTRODUCTION}

Writing is not only one of the four basic language skills in English learning, it is also an important means of exchanges of ideas in social lives. It is usually considered to be a sign of one's language competence and comprehensive quality. But for most Chinese learners, English writing is still a big problem. Students at university level suffer from a limited lexicon and weak language foundation though they work hard and do well in reading exam. Further, they often have difficulty in organizing their ideas in proper ways, or even they are usually short of ideas for a given topic.

As far as some students are concerned, Winer (1992) revealed that producing a piece of writing has always come after a period of suffering and they are experiencing complete and total anxiety over writing. To get students out of the plight, to improve their writing power and efficiency in writing teaching, here in this paper it is suggested that different approaches be introduced to play different roles to produce a combined effect.

\section{A Research into the Causes of Students’'Weak Performance in Writing}

For majority of Chinese students, English is a second language that is taken as a compulsory course in both high school and university. In spite of the fact that much time and efforts have been devoted to English learning in their secondary school, they still cannot make proper use of English to express themselves in college. Possibly I suppose the following may be the causes:

First, many college students come from the local areas relatively backward in the development of economics and education, especially from the isolated areas in the countryside, where there is always an urgent need for the qualified teachers of English, which greatly affects the English level of new students in college.

Second, students have seldom been instructed and required to carry out real writing tasks before getting higher education though they have studied English for more than six years since. Neither have they been specially trained with specific writing skills. Mostly, their writing task was only the translation of sentences or paragraphs as required, necessary the structured sentences translation and practices are, still, there is a long way to go for teachers to guide students to produce satisfactory written works and to be skilled writers.

Third, because of exam-oriented teaching objectives and schedules, students do not have much independent time at their disposal to read wide, read and think for themselves, They have not gone through many different lives and developed much their own views either. Further, what they have acquired from text learning alone cannot meet the requirements of different writing tasks. Therefore, weak awareness of thinking and limited expanse of ideas pose a more serious problem than language foundation and skills, thus the cultivation of students' awareness of thinking and improvement of their mind should be an essential component of English writing course.

For the above-mentioned causes, students often run into difficulty in writing and such unsuccessful experience discourages them from writing competently and with confidence. It is quite easy for students to give English writing up or put it in a position secondary to the other language skills. This is what this paper is mainly concerned about.

\section{Literature ReVIEW ON Process AND Product Writing}

Process Writing. Donald M. Murray(1972) published a brief manifesto titled "Teach Writing as a Process Not Product", which attracted wide attention from many writing teachers all over the world. Ten years later, Maxine Hairston(1982) argued that the teaching of writing had undergone a "paradigm shift" in moving from a focus on written products to writing processes. 
Mahon(1992)pointed out that process writing approach involves teaching pupils strategies to help them express themselves in writing through the act of writing. Students go through five interrelated phases before they produce the final products. The five important steps in process writing include pre-writing phase, brainstorming, drafting, revising and editing, finished product.

From what has been introduced in the previous paragraph, we can see that the process of writing can be divided into manageable parts and it involves the practice of speaking, reading and writing in an intended writing target. It helps students to work together and share ideas and develop ideas and finally achieve their task in a easier and more efficiently way.

Product writing. Product writing is usually considered to be a long established way for teaching writing. Traditionally, students are encouraged to model after a text, which is usually studied and analyzed before writing job is assigned. Usually, model texts are carefully read with much attention to the type of reading, language, paragraphing and techniques used in organizing sentences and paragraphs. More focus is placed on the organization of ideas and the control of language practice. Production of ideas and free mind is much neglected and cultivation of mind is thus missed.

Another problem in product approach lies in the fact that writing is simply taken as a way to the controlled practice of language fluency, writing acts as a mirror to reflect how well students can use the vocabulary and the writing technique they have been taught to produce the desired composition In product writing, more emphasis is put on the end result of the required composition rather than on the improvement of mind and collaboration of team work.

\section{AdDREssing The COMMON WRITING Problems}

According to the modern FLT theories, the language learning process is the combination of input, intake (processing and memorizing in listening and reading) and output (speaking and writing). Two basic elements-- comprehension and production are always contained in English teaching, which can be regarded as two stages: input and output. FLT in China aims to cultivate students' language application based on enough comprehensible input material. Two objectives are usually to be desired in listening and reading classes: one is to improve comprehension through the comprehensible input; the other is to present usage of language for students to imitate in speaking and writing.

\section{A. Building Language Foundation through Reading}

Reading, as one of the essential skills of language practice, has long been recognized to play a significant role in the overall acquisition of any language, the same is true of its role in the development of students' writing ability. As Gebhard (1996) pointed out that the useful things in writing are word choice, use of appropriate grammar, syntax, mechanics and organization of ideas into a coherent and cohesive form. In in-school and out of school situation, reading and writing works as an essential processes in learning new information, in translating message, in making sense of new ideas and for exchanging those new ideas with others. It is chiefly through reading process that students can accumulate vocabulary, build solid language foundation and grow familiar with the organization of an essay, all of which makes the completion of a piece of good writing possible.

In terms of linguistic competence, poor command of vocabulary and inability to use it properly may be one of the major obstacles in the preparation for written work for Chinese college students. Vocabulary is often more important and challenging than grammar in that vocabulary is very infinite and words are often more complex than they appear to be, for words are not isolated from but associated with a certain type of context or situation. thus they behave differently in different context. Therefore, special attention has to be directed to the meaning and usage of words and expressions in text reading.

Further, it is important to recognize that students do not learn well from the only first presentation of the new language items alone. They need to be introduced or even reintroduced to the new items until they can have a full command of what they have learnt and produce them automatically when required. To reach this goal, students are often asked to practise a certain number of language models, such as word substitution, sentence patterns, structure of paragraphs, etc. In many English textbooks, there are always such items of exercise " replace A with B", "reorganize the following sentences after the models" or "compose a paragraph on the provided structure", etc. The repeated phrases and structures are usually the most often used ones. To be familiar with them is really a great advantage for students to be fluent users of English in writing.

It has been acknowledged that vocabulary learning, directed practice of language patterns, model writing and reading are essential to students if they are expected to make a steady progress in writing skills. Frequent exposure to different readings facilitates the capacity of students in using the language forms functionally. Yet, a balance must be kept carefully between the controlled language practice and the cultivation of creativity intended for the writing process.

\section{B. Organizing Oral Activities}

Speaking, like writing, has been regarded as an important means of language production, a means of communication . Here I am not dwelling on its general function in human communication, but only on its specific role as an introductory stage to writing. Judged from the types of speaking tasks, the activities purposefully designed in class are the controlled or semi-controlled ones. 
For example, after a detailed study of texts, students finally come to deal with certain learning tasks where students are required to take a combined practice of speaking and writing. Often it is organized as follows: students are divided into small groups to discuss the questions in English, most of the questions are connected with the theme of the text. Group activities sometimes vary depending on the type of the text, so speech contest, role play and mock debate are often brought to classroom as an alternative to group discussion. After the discussion or play, they are required to write an article on the basis of their discussion with the questions serving as a framework.

From this arrangement of classroom activities, we can expect that writing can be facilitated to some degree when preceded by theme-related oral activities. In this way, students are less likely to be short of language and supporting details needed in expressing themselves. Another equally important point is that this arrangement is in agreement with the principle of process writing approach that group prewriting discussion is introduced as an important component of writing instruction. In the process, students can make up for each other's deficiencies, learn from each other and meet each other's needs.

\section{Exploring Knowledge and Cultivating Creativity}

In reading of my students' papers, I always find students are rather weak in expanding paragraphs with different ideas or from different perspectives. It seems that they can not venture beyond the instruction of teachers and textbooks for their limited absorption of knowledge and fixed ways of thinking, thus their writing can be very dull and dry, let alone free creation. To solve the problem, I think exploring reading and cultivation of creativity are much valuable.

Generally, the value of an excellent piece of writing does not only fully lie in its correct use of words, grammar and coherent organization, but equally lie in the ideas it produces and feelings it conveys. Those masterpieces that have inspired or shaped generations of readers are mostly originated from the minds that do so much reading, thinking and exploring that they gain the unique perception of the world inaccessible to ordinary people. Then it follows that value of a writing also depends on what a writer can communicate or share with a reader.

In the course of text reading, teachers can not be much satisfied that students have understood what words seem to convey to them. We should go further to ask students to explore what is hidden under the lines, what is most instructive and enlightening to them. After class, mind-improving books will be introduced as a supplementary reading task to push back their horizon and improve their mind, for these readings are treasure of learning and a rich source of human civilization. from which young students can constantly learn beauty, wisdom and life and will then cherish it all their lives. A student writer nurtured with such education is expected to create a piece of compelling work.

To nurture creative spirit in learners is one of the fundamental goals of quality-oriented education and also the contributing factor for attainment of originality in writing (Chen QingSong, 2005) .Writing, like the art of painting, is a type of creative mental activity. Originality is highly valued in the process of creation of written work. A writer is usually as much appreciated for his creativity in his work as a painter is in his art work. Because of the important role that creativity plays in the production of written work, teachers should include fostering of creative power in the whole process of writing teaching, in students' life experience, even in every aspect of their life.

To have curiosity about an unknown world, to have dream about future and to have imagination over what they long for are the common traits among young people. It lies heavily on teachers' shoulders to awaken, activate and satisfy all these to promote life-long creative spirit in them. It is also a teacher's duty to encourage students to try out new approaches to familiar topics or to view them from different perspectives, or even to question what has been long established. Being constantly guided to this direction, students will gradually learn to think for themselves and develop new, free ways of thinking. Then he will no longer find the completion of a piece of creative work threatening or forbidding.

\section{Providing Supportive Environment}

Ann Ramie's (1983) says that for second language learners, who need more time and opportunity to keep using the language with others, group work is especially beneficial. For teachers, working in a co-operative way is an valuable way of instruction and it helps much in professional development. Likewise, for students, the co-learning practice facilitates mutual growth and sharing experience. It helps to produce an expected effect. For example, in the important steps of writing, such as pre-writing, brainstorming, drafting, revising, editing and finished product, group work plays an important role. In brainstorming stage, students can freely associate and exchange ideas with their peers in groups, they can make up for each other's deficiencies, learn from each other and meet each other's needs. Their imagination can be inspired by so many different ideas from peers that they no longer worry about inadequacy of ideas. As a result of sharing ideas, students do not fear their ideas will be rejected by teachers, for they would have the whole group to back themselves up, which promotes confidence and interest to write and also improves quality in writing.

In revising and editing stages, students are often asked to read each others' works, either in pairs or in groups, and give comments to each other for revision before the final draft is handed in and assessed by the teacher. Students like to incorporate the exchanging of drafts to become the readers of each others' works. Qian Xinyu (2010) observed that this is an important part of the writing experience as it is by responding as readers that students develop an awareness of the fact that they are producing something to be read by someone else. Peregoy and Boyle (1993) commented that a great deal of excitement is generated when they know that they will share their final product with others. As the students see their writings read by others, the sense of achievement is great and this will encourage them to write more. Displays and 
sharing their works make their writing authentic and it is a good way to promote writing.

Ferris (1995) remarked that teacher feedback is also considered to be a crucial factor that can improve students' writing competence and grammar knowledge. However, in the context of Chinese higher education, teachers regard writing instruction as a time-consuming and unrewarding task due to various factors like large class size, heavy workload and exam-oriented teaching background. In the previous study, Zamel (1985) considered that L2 English writing teachers have often viewed students' writings as the final product, thus they gave comments mostly on language forms and ignored the importance attached to the idea development, organization and logic in students' writings. Zamel (1985) assumed instructors who focused on accuracy were more likely to be a language teacher but not writing instructor.

The feedback from teacher can be taken as direct one and indirect one. Former deals with errors that are considered as difficult and thorny problems for students to comprehend or revise. Hence teachers would directly give accurate response to correct students' errors. Whereas, latter is given by utilizing circle, underline or other special marks to indirectly point out students' errors. It is argued by scholars like Ferris (2003) and Lee (2008) that indirect comment would be beneficial for learners to improve long-term writing skills and enhance their independent problem-solving capacities. When teachers provide indirect comments, students are more likely to revise their draft by themselves rather than only take a look at teachers' direct and explicit feedback.

Zamel (1985) supposed that if writing instructor mark all the errors, the result would turn writing teachers into merely grammar lecturers due to extreme emphasis on students' language errors. It is argued that selective comment on students' errors would be effective for teachers and learners because it is impossible to create an errorless written piece.

What's more, in terms of teachers' written comment, Lee (2008) advocated that written commentary, which includes both surface level (referring to linguistic errors) and global level (regarding comments on idea development and organization), need to be unambiguous, specific and comprehensible statements related to the draft. When written commentary is addressed, both criticism and praise statements need to be taken into consideration.

\section{E. Integrating Product Writing and Process Writing}

Both product writing and process writing are equally important, the two approaches are not necessarily incompatible, they have respective strength and weakness, the choice as to which one will be employed is determined by such important factors as the type of student, the studied text type and many other factors.

Generally, for Chinese college students, English is a second language, in which they receive insufficient specialized training and little regular practice in language production. According to Carroll (1984), the process approach is believed by many teachers to be inappropriate for students whose English is limited. Gebhard (1996) suggested that it is essential that teachers be strict with students in word choice, use of appropriate grammar, syntax, mechanics and organization of ideas into a coherent and cohesive form. Teachers have to emphasize the production of neat and grammatically correct pieces of compositions by using structured sentence patterns and controlled vocabulary so that later students can go on writing smoothly. Such a product-orientated approach prepares students technically for the start and completion of composition and then for error correction in a final revised form of writing.

But on the other hand, process writing has a tendency to organize target-aimed classroom activities which help students to be better language users: brainstorming, group discussion, editing and re-writing. In the whole course of process writing, the most important thing is the flow of ideas, the teacher needs to wake up students' desire to get them into thinking how to get to a writing topic: how to generate ideas by brainstorming and discussion; how to extend ideas, and judge quality and usefulness of ideas; how to organize ideas into drafts: how to revise drafts based on peer feedback. It is a complex mental activity and collaborative work, which contributes much to the improvement of writing quality.

Both product and process approach play a shared role in the promotion of progress in the writing power of college students. As Raimes (1985) observed that writing teachers should consider the need to attend to product as well as process. Conner (1987) advised that our students should be taught not only heuristic devices to focus on meaning, but also heuristic devices to focus on rhetorical and linguistic features after the ideas have found some form. In other words, it is not a matter of adopting one approach for certain students, but rather a matter of marrying the two.

\section{CONCLUSion}

To sum up, learning to write is a long, complex and creative process in which a series of language skill practice and the related activities are involved and interrelated. On the one hand, practice of every other language skill helps to bring about improvement in writing proficiency, well-targeted and extended reading and speaking helps to bring about proper, fluent and well-organized creation of writing. On the other hand, constant exposure to different sources of thoughts through different designs works to improve the mind of students. With guiding principles in terms of peer feedback rubric and adequate teacher scaffolding, students tend to revise their drafts more successfully, based on the constructive feedback. Therefore, writing practice, like the practice of the other language skills, is a part of language learning and a part of quality-oriented education. If English teachers have a deep understanding of the interrelation between writing and the contributing factors, place equal stress on language form and content, integrate writing into the whole process of teaching and learning, then all the efforts made by both teachers and students will be much rewarded. 


\section{REFERENCES}

[1] Ann Raimes. (1983). Techniques in Teaching Writing. Oxford: Oxford University Press.

[2] Carrol, J.A. (1984). Process into product: Graduate school and beyond. New York: Guildford, pp. 315-333.

[3] Chen Qingsong. (2005). On constructing new concept of English writing instruction. Teaching English In China. 4:107-110.

[4] Connor, U. (1987). Research frontiers in writing analysis. TESOL Quarterly 21(4): 677-696. http://dx.doi.o $\mathrm{rg} / 10.2307 / 3586989$.

[5] Donald M. Murray. (1972). "Teach Writing as a Process Not Product" The Leaflet (November, rpt. in Cross-Talk in Comp Theory, 2nd ed., ed. Victor Villanueva, Urbana: NCTE, 2003.

[6] Ferris D R. (1995). Student reactions to teacher responses in multiple draft composition classrooms. TESOL Quarterly, 1995, 29(1), 33-53.

[7] Gebhard, J. G. (1996). Teaching English as a Foreign or Second Language. Michigan: The University of Michigan Press.

[8] Lee I. (2008). Understanding teachers' written feedback practices in Hong Kong secondary classrooms. Journal of Second Language Writing, 2008, 17(2), 69-85.

[9] Mahon, T. (1992). From sentence to story: A process approach to the development of composition skills in the primary school. In Lau, M. \& Murphy, M. (Eds.) Developing writing: purposes and practices. Hong Kong: Institute of Language in Education, Education Department.

[10] Maxine Hairston. (1982). "The Winds of Change: Thomas Kuhn and the Revolution in the Teaching of Writing" CCC 33 (1982), pp. 76-88, rpt. in The Norton Book of Composition Studies, ed. Susan Miller, New York: Norton. http://dx.doi.org/10.2307/357846.

[11] Peregoy, S and Boyle, O. (1993). Reading, writing and learning in ESL. A resource book for K-8 teachers. New York: Longman.

[12] Qian, Xinyu. (2010). A balanced approach to the teaching of intermediate-level writing skills to EF students. English Language Teaching. 2010, Vol. 3, No.2, pp13-16.

[13] Raimes, A. (1985). What unskilled ESL students do as they write: A classroom study of composing. TESOL Quarterly 19(2):229-358. http://dx.doi.org/10.2307/3586828.

[14] Winer, L. (1992). 'Spinach to chocolate': Changing awareness and attitudes in ESL writing teachers. TESOL Quarterly 26(1):57-59. http://dx.doi.org/10.2037/3587369.

[15] Zamel V. (1985). Responding to student writing. TESOL Quarterly, 29(1), 79-101.

Xiu Zeng was born in Nanchang, China in 1964. She received her M.A in British language and literature from Jiangxi university (Nanchang university thus named today), China in 1986.

She is currently an associate professor in the Foreign Language School, Nanchang Normal University, Nanchang, Jiangxi, China. Her research interests include American literature.

Ms. Zeng is a member of the Jiangxi Association of Foreign Language Teachers. 